\title{
Viljelijän oman työvoiman riittävyys maitotilalla
}

\author{
Markku Lätti ja Veli-Matti Tuure ${ }^{1)}$, Perttu Pyykkönen ${ }^{2)}$
}

${ }^{1)}$ TTS Työtehoseura ry, Kiljavantie 6, 05201 Rajamäki, etunimi.sukunimi@tts.fi

${ }^{2)}$ Pellervon taloustutkimus PTT, Eerikinkatu28 A 00180 Helsinki, etunimi.sukunimi@ptt.fi

\section{TIIVISTELMÄ}

Maatalouden voimakkaan rakennekehityksen myötä viljelijän oman työvoiman riittävyys nousee keskeiseksi tarkastelun kohteeksi. Tässä tutkimuksessa mallinnettiin tuotantoa laajentavan maitotilan työt viljelijäperheen oman työvoiman riittävyyden selvittämiseksi. Perusvaihtoehtona on nykyistä keskikokoa vastaava tila, joka hoitaa itse koko rehuntuotannon ja lannanlevityksen. Tarkasteltavia laajentamisvaihtoehtoja ovat tilakoon kasvattaminen yhden ja kahden lypsyrobotin tilakokoluokkaan. Lypsyrobottivaihtoehdon lisäksi myös asemalypsyvaihtoehdot samoissa karjakokoluokissa ovat mukana laajentamisvaihtoehdoissa. Lisäksi kahden robotin kokoluokan maitotilan malleissa on mukana hiehonkasvatuksen ulkoistavan tilan mallit.

Työmäärälaskelmat tehtiin maatalouden standardiaikatietoja käyttävällä TTS-Managerohjelmalla. Laskelmia täydennettiin peltotöiden siirtymiin, kuljetuksiin ja pellolla tapahtuviin valmisteluihin liittyvällä erillisellä taulukkolaskentaohjelmapohjaisella laskelmalla. Näitä laskelmia varten mallitiloille määritettiin tilusrakenne vastaavankokoisten Pohjois-Savossa sijaitsevien maitotilojen tilusrakenteiden perusteella pohjautuen vuoden 2012 Peltolohkorekisteritietoihin. Säilörehunkorjuuketjut valittiin tilakokoluokan korjuukapasiteettitarpeen perusteella.

Jos noin 70 lehmän lypsyasematilojen yrittäjät haluavat pitää kiinni kohtuullisesta vuosityömäärästä, tilalle tarvitaan viljelijäperheen kahden hengen työpanoksen lisäksi yhden palkatun työntekijän työmäärää vastaava työpanos, ellei peltotöitä ulkoisteta reilusti. Vastaavan kokoisilla robottilypsytiloilla pärjätään kahden hengen työpanoksella. Kahden robotin maitotilalla kotieläintyöt hoituvat vielä kahden henkilön voimin, mutta peltoviljelytöihin ja muihin tilan töihin tarvitaan kausityövoimaa. Lisäksi peltoviljelykaluston kapasiteettia on kasvatettava, jotta työt voidaan tehdä oikea-aikaisesti, ja sesonkitöihin tarvitaan työvoimaa, jos kaikki työt tehdään tilalla itse.

Ulkoistamalla töitä voidaan vaikuttaa lähinnä sesonkityöntekijöiden sekä peltotöiden koneinvestointien tarpeeseen. Lisäksi hiehojen kasvatuksen ulkoistaminen vähentää nuorkarjatilojen tarvetta, mikä merkitsee pienempää rakennusinvestointia. 140 lehmän asemalypsytilalla työntekijätarve nousee neljään työntekijään, jos kaikki työt tehdään itse. Lisäksi tarvitaan sesonkityöntekijöitä sadonkorjuun työsesonkeihin. Ulkoistamalla peltotöitä tai hiehonkasvatus 140 lehmän asemalypsytilalla selvitään kolmella kokoaikaisella työntekijällä, mutta lisäksi tarvitaan $1 / 4-1 / 2$ palkkatyöntekijän työpanos (yksi kausityöntekijä).

Maitotilan suunnitellessa merkittävää muutosta nykyiseen tuotantoonsa on tärkeää, että työmäärä- ja työvoimaresurssikysymykset otetaan huomioon. Tällöin tila voi päätöksiä tehdessään valita sille parhaiten sopivan vaihtoehdon tarjolla olevista ja pitää kunkin henkilön työkuorma kohtuullisena. Näillä ratkaisuilla tuetaan sekä maataloustyötä tekevien jaksamista että kestävää ja laadukasta maataloustuotantoa.

Asiasanat: Työvoima, työmäärä, lypsykarjatila, tilamalli, asemalypsy, robottilypsy, laajentaminen 


\section{Johdanto}

Maatalouden rakennekehityksen myötä viljelijän oman työvoiman riittävyys nousee keskeiseksi tarkastelun kohteeksi. Työvoimavaltaisena tuotantosuuntana lypsykarjatiloilla oman työvoiman riittävyyden rajat tulevat vastaan useissa muutostilanteissa, kun lähtötilanteessa tilan työt on hoidettavissa vielä viljelijäperheen omin voimin, mutta uudessa tilanteessa tilakoko kasvaa tämän rajan yli.

Tällä hetkellä keskikokoisilla lypsykarjatiloilla on usein käytössä parsinavetta, jota on laajennettu mahdollisesti useastikin eläinmäärän kasvaessa. Jos karjassa on yli 35 lehmää, lypsyn työnmenekki on pihatossa pienempi kuin parsilypsyn työnmenekki (Auernhammer 1990). Pihatot mahdollistavatkin työmäärän ja työkuormituksen vähentämisen - sekä siten eläinmäärän lisäämisen. Jossakin vaiheessa tilakoon kasvaminen ylittää kuitenkin sen rajan, johon asti tilan oma työvoima riittää. Selviytyäkseen eläinmäärän lisäyksestä johtuvasta kasvaneesta työkuormasta viljelijöillä on erilaisia strategisia mahdollisuuksia yksittäisten töiden ulkoistamisesta ulkopuolisen työvoiman palkkaamiseen, tilayhteistyöhön, yhteisyrityksiin ja eräiden töiden kokonaan tai osittaiseen automatisointiin.

Yleisimpiä urakoitavia maataloustöitä ovat puinti, viljankuivaus, kasvinsuojeluruiskutukset ja pyöröpaalaus (Palva 2013). Urakoitsijaa käytetään lähinnä oman työkuorman vähentämiseksi. Tärkeä perustelu on myös työnlaatu. Suurimpia urakointiin liittyviä haasteita ovat puolestaan töiden ajoittumisen ennakointi ja osittain siihen liittyen urakointitilauksen tekeminen riittävän ajoissa, jotta urakoitsijan saa vielä paikalle.

Käytännössä karjatiloille palkataan työvoimaa tilan ulkopuolelta joko tilan laajentumisesta johtuneen kasvaneen työmäärän takia tai paikkaamaan tilan vähäistä omaa työvoimaa $(\mathrm{mm}$. tilan ulkopuolella työssä käymisen takia). Koska työvoimatarve riippuu ainakin näistä kahdesta syystä, selvää yhteyttä karjakoon ja palkkatyövoiman tarpeen välillä ei välttämättä esiinny. Niinpä esimerkiksi saksalaistutkimuksessa, jossa oli mukana 15 baijerilaista lypsykarjatilaa ja pihatoissa 58-222 lehmää, palkkatyövoiman osuus kirjatuista lypsykarjatilan töistä vaihteli välillä 8,6-34,8 \%. (Mačuhová ym. 2011)

Tutkimuksen tavoitteena oli mallintaa tuotantoa laajentavan lypsykarjatilan työt viljelijäperheen oman työvoiman riittävyyden selvittämiseksi. Perusvaihtoehtona oli nykyistä keskikokoa vastaava tila (30 lehmää sekä uudistukseen tarvittava nuorkarja), joka hoitaa itse koko rehuntuotannon ja lannanlevityksen. Tarkasteltavia laajentamisvaihtoehtoja olivat tilakoon kasvattaminen yhden ja kahden lypsyrobotin tilakokoluokkaan. Lypsyrobottivaihtoehdon lisäksi myös asemalypsyvaihtoehdot samoissa karjakokoluokissa olivat mukana laajentamisvaihtoehdoissa. Lisäksi kahden robotin kokoluokan lypsykarjatilan malleissa oli mukana hiehonkasvatuksen ulkoistavan tilan mallit.

\section{Aineisto ja menetelmät}

Perusvaihtoehtoa kuvaavan tilan kooksi määritettiin 30 lehmää ja tarvittava uudistuseläinmäärä. Nuorkarjan määrä määritettiin siten, että tilalla oletetaan kasvatettavan kaikki lehmävasikat, joista osa käytetään uudistukseen ja osa myydään siemennettyinä hiehoina. Vasikkakuolleisuudeksi määritettiin $5 \%$ syntyvistä lehmävasikoista. Sonnivasikat myydään välitykseen ternikauden jälkeen. Näin hiehoja on perusvaihtoehtomallissa keskimäärin $25 \mathrm{kpl} \mathrm{ja} \mathrm{juottovasikoita} \mathrm{keskimäärin} 3 \mathrm{kpl}$ (taulukko 1).

Yhden lypsyrobotin kokoluokan tilamalli määritettiin karjalle, jossa on 70 lehmää (lypsylehmät + ummessa olevat lehmät) ja 66 nuorkarjaan kuuluvaa eläintä (60 hiehoa ja 6 juottovasikkaa). Vastaavasti kahden lypsyrobotin kokoluokan tilamalli määritettiin 140 lehmän karjalle ja 132 nuorkarjaan kuuluvalle eläimelle. Kyseisillä lehmämäärillä lypsyrobotin kapasiteetti on tehokkaassa käytössä. Määrät ovat hieman suurempia kuin yhden ja kahden robotin tiloilla keskimäärin toteutuu. Nuorkarjan määrän määritysperusteet olivat samat kuin perusmallin kohdalla.

Taulukko 1. Tilamallien kuvaukset.

\begin{tabular}{|c|c|c|c|c|c|c|c|c|c|c|c|}
\hline \multirow{2}{*}{ Tilamallityyppi } & \multicolumn{3}{|c|}{ Navettatyyppi \& lypsy- ja ruokintatapa } & \multicolumn{3}{|c|}{ Eläimet, kpl } & \multicolumn{5}{|c|}{ Pellonkäyttö, ha } \\
\hline & Tyyppi & Lypsy & Ruokinta & Lehmät & Nuorkarja & Vasikat & Säilörehu & Vilja & Laidun & Heinä & Yhteensä \\
\hline Perusvaihtoehtotila & parsi & putki 4 yks.+irr. & erillis + laidun & 30 & 25 & 3 & 18 & 7 & 6 & 3 & 34 \\
\hline \multirow{2}{*}{70 lehmän tila } & pihatto & asema $2 \times 6$ & erillisruokinta & 70 & 60 & 6 & 62 & 15 & - & - & 77 \\
\hline & pihatto & robotto & erillisruokinta & 70 & 60 & 6 & 62 & 15 & - & - & 77 \\
\hline \multirow{4}{*}{140 lehmän tila } & pihatto & asema $2 \times 10$ & seosrehu & 140 & 121 & 11 & 124 & 31 & - & - & 155 \\
\hline & pihatto & asema $2 \times 10$ & seosrehu & 140 & 7 & 11 & 97 & 24 & - & - & 121 \\
\hline & pihatto & robotto $\times 2$ & seosrehu & 140 & 121 & 11 & 124 & 31 & - & - & 155 \\
\hline & pihatto & robotti $\times 2$ & seosrehu & 140 & 7 & 11 & 97 & 24 & - & - & 121 \\
\hline
\end{tabular}


Kahden lypsyrobotin kokoluokan tilamalleille laskettiin työmäärä myös hiehonkasvatuksen ulkoistamistilanteessa (Kauppinen 2012). Laskelma perustuu noin $30 \%$ :n uudistamiseen sekä juottovasikoiden ja $2 \mathrm{kk}$ ennen poikimista tilalle palaavien hiehojen kasvattamiseen tilalla, jolloin nuorkarjamääräksi tilalla saadaan 7 hiehoa ja 11 vasikkaa (taulukko 1). Perusvaihtoehdossa eläimet ovat parsinavetassa, kun taas karjakooltaan suuremmissa tilamallivaihtoehdoissa eläimet ovat pihatossa.

\section{Tilamallien tilusrakenteen taustalla todelliset peltolohkokuviot}

Tilamalleista vain perusvaihtoehdossa eläimiä laidunnetaan. Sisäruokintakauden pituutena käytetään 250 päivää ja laidunnuskauden vastaavasti 115 päivää. Säilörehunurmen viljelypinta-alan määritys perustuu nykyaikaisiin nautojen rehuntarvetaulukoihin. Lehmien säilörehumääränä malleissa käytettiin $40 \mathrm{~kg} / \mathrm{vrk}$ ja nuorkarjan keskimäärin $14 \mathrm{~kg} / \mathrm{vrk}$. Säilörehun kuiva-ainepitoisuus laskelmissa on $30 \%$ ja sisäruokintakauden pituus pihattomalleissa 365 vuorokautta. Säilörehusatona viljelypinta-alan määrityksessä käytettiin keskituoresatoa $22000 \mathrm{~kg}(6600 \mathrm{~kg} \mathrm{ka} / \mathrm{ha}(30 \%))$. Näin nurmialaksi saatiin (taulukko 1) perusvaihtoehdossa noin 27 ha, yhden robotin tilakokoluokan malleissa 62 ha ja kahden robotin tilakokoluokan malleissa 124 ha (hiehojen kasvatus ulkoistettuna 97 ha). Rehuviljan satotasona käytettiin $4000 \mathrm{~kg} / \mathrm{ha}$. Viljan viljelyn pinta-ala määritettiin viiden vuoden viljelykierron perusteella. Puuttuva vilja ostetaan.

Peltolohkojen keskietäisyyksinä (maantie-etäisyys) käytettiin perusvaihtoehtotilan mallissa 2,32 $\mathrm{km}, 70$ lehmän tilan malleissa 4,46 km ja 140 lehmän tilan malleissa 8,29 km. Nämä perustuvat vuoden 2012 Peltolohkorekisteritietoihin Pohjois-Savon maitotilojen (30-80 ha; N=400) peltolohkojen keskietäisyyksistä. Peltolohkojen keskimääräiset linnuntie-etäisyydet muunnettiin maantieetäisyyksiksi TTS:n toteuttamassa toisessa tutkimusprojektissa olleen suuren esimerkkitilan noin 60 peltolohkon linnuntie- ja maantie-etäisyyksien määrittämiseen perustuvan kertoimen avulla.

Lietteen levityspinta-ala määritettiin vuodessa mallin eläinmäärällä syntyvän lietteen määrän (lehmät $24 \mathrm{~m}^{3} / \mathrm{v}$ ja nuorkarja keskimäärin 11,7 m³ (MMM 2001); tilamalleittain $718 \mathrm{~m}^{3}, 2452 \mathrm{~m}^{3}$, $4904 \mathrm{~m}^{3}$ ja $\left.3571 \mathrm{~m}^{3}\right)$ ja hehtaarikohtaisen levitysmäärän $\left(35 \mathrm{~m}^{3}\right)$ perusteella. Malleissa ei oteta kantaa siihen, levitetäänkö lanta omille pelloille (mahdollinen säilörehun hygieniariski) vai jonnekin muualle. Oletuksena kuitenkin käytettiin mallin lohkotietoja (lohkomäärä ja etäisyydet).

\section{Aikastandardiaikoihin perustuva työmäärälaskenta}

Työmäärälaskelmat tehtiin maatalouden standardiaikatietoja käyttävällä TTS-Manager-ohjelmalla (Kaila ja Tuure 2007). Osa käytetyistä standardiaikatiedoista on peräisin saksalaisesta maatalouden standardiaikajärjestelmästä (KTBL 2010). Laskelmia täydennettiin peltotöiden siirtymiin, kuljetuksiin ja pellolla tapahtuviin valmisteluihin liittyvällä taulukkolaskentaohjelmapohjaisella laskelmalla. Näitä laskelmia varten mallitiloille määritettiin tilusrakenne vastaavankokoisten Pohjois-Savossa sijaitsevien maitotilojen tilusrakenteiden perusteella pohjautuen vuoden 2012 Peltolohkorekisteritietoihin.

TTS-Manager-ohjelmalla määritettiin kaikkien muiden maatilatalouden töiden paitsi peltotöiden siirtymien ja kuljetusten työnmenekit. Laskennat perustuvat keskimääräiseen työteholuokkaan (standardiaikoihin) ja tyypillisiin karjakokoluokan menetelmiin ja koneisiin. Asemalypsyyn perustuvissa malleissa lypsyaseman koko määritettiin Lypsykarjapihatoiden toiminnallisuus -tutkimusten (LYTO1 ja LYTO2) kohdetiloilla esiintyvien asemakokojen perusteella (Kivinen ym. 2007, Tuure ym. 2013).

Säilörehunkorjuuketjut valittiin tilakokoluokan korjuukapasiteettitarpeen perusteella. Perusvaihtoehtotilalla korjuu tapahtuu kaksoissilppurilla, muissa tilakokoluokissa tarkkuussilppurilla. Korjuuketjun työkoneyksiköiden ja henkilöiden lukumäärä määräytyy osittain kuljetusetäisyyden perusteella; lähtökohtana on, että korjuukone saa työskennellä jatkuvasti ja kuljetuskapasiteettia on käytettävissä riittävästi. Laskelmat perustuvat tilamallien peltolohkojen keskietäisyyksiin, jolloin keskietäisyyden kasvaessa (tilan peltoalan kasvaessa) kuljetusyksiköitä tarvitaan enemmän.

Siirtymis- ja kuljetusaikojen laskennassa pohjana käytetyt ajonopeudet perustuvat TTS:ssä tehtyihin aikaisempiin tutkimuksiin (mm. Tuure 2012) sekä yksittäiseltä isolta maatilalta saatuihin, tilalla mitattuihin ajonopeuksiin. Keskimääräinen ajonopeus määräytyi mallinnuksissa lisäksi peltojen maantie-etäisyyksien perusteella siten, että alle $1 \mathrm{~km}: n$ etäisyyksillä käytettiin ajonopeutta $12 \mathrm{~km} / \mathrm{h}$ (pihatie/peltotie), 1-5 km:n etäisyyksillä $20 \mathrm{~km} / \mathrm{h}$ (paikallistie) ja yli $5 \mathrm{~km}: n$ etäisyyksillä ajonopeutta 40 $\mathrm{km} / \mathrm{h}$ (maantie). Lohkojen lukumäärä on suurusluokaltaan peltopinta-alaltaan vastaavien kokoisten pohjoissavolaisten maitotilojen (30-80 ha:n maitotilojen Peltolohkorekisteritiedot vuodelta 2012) lohkojen lukumäärän suuruinen. 


\section{Tulokset ja tulosten tarkastelu}

\section{Kokonaistyötuntimäärä lypsykarjatiloilla}

Kokonaistyömäärä 30 lehmän parsinavettatilalla on työmäärälaskelmien mukaan 3249 tuntia vuodessa (taulukko 2). Vastaavasti 70 lehmän pihattotiloilla kokonaistyömäärä on 4857-6540 h/vuosi ja 140 lehmän pihattotilalla 5853-8290 h/vuosi. Lypsyrobottitiloilla kokonaistyömäärä on noin $25 \%$ pienempi kuin vastaavankokoisella asemalypsytilalla. Kotieläintöiden osuus kaikista tilan maataloustöistä vaihtelee tilamalleittain välillä 61-74 \%. Kotieläintöiden osuus on pienin lypsyrobotti- ja suurin asemalypsytiloilla.

Taulukko 2. Kokonaistyömäärä (h/vuosi) lehmämäärältään erikokoisilla parsi-, asema- ja robottilypsytiloilla

\begin{tabular}{|l|c|ccc|ccc|}
\hline & Parsinavetta & \multicolumn{4}{|c|}{ Asemapihatto } & \multicolumn{3}{c|}{ Robottipihatto } \\
& 30 leh.+28 nk & 70 leh.+66 nk & 140 leh.+132 nk & 140 leh.+18 nk & 70 leh.+66 nk & 140 leh.+132 nk & 140 leh.+18nk \\
\hline Karjanhoitotyöt & 2187 & 4827 & 5809 & 5364 & 3144 & 3859 & 3595 \\
Säilörehutyöt & 125 & 417 & 765 & 595 & 417 & 765 & 595 \\
Muu peltoviljely & 106 & 80 & 130 & 94 & 80 & 130 & 94 \\
Lannanajo ja levitys & 36 & 165 & 213 & 158 & 165 & 213 & 158 \\
Suunnittelu ja johtaminen & 421 & 421 & 677 & 715 & 421 & 677 & 715 \\
Muut työt & 374 & 630 & 696 & 696 & 630 & 696 & 696 \\
\hline YHTEENSÄ h/vuosi & 3249 & 6540 & 8290 & 7622 & 4857 & 6340 & 5853 \\
\hline
\end{tabular}

Tilamallien mukaiset työmäärät ovat keskimäärin $21 \%$ pienempiä kuin MTT:n kannattavuuskirjanpitoon kuuluvilta lypsykarjatiloilta kerätyt (MTT:n Taloustohtori 2011) toteutuneet viljelijäperheen ja palkkaväen yhteenlasketut maatalouteen käytetyt työpanokset samankokoisilla tiloilla (kuva 1). On tavallista, että työnmenekkitiedoista lasketut kokonaistyömäärät ovat toteutuneita työmääriä pienemmät, sillä malleissa mukana olevat työt eivät täysin kata kaikkia maatiloilla tehtävää työtä ja mm. säätekijät todellisuudessa hidastavat tai jopa keskeyttävät peltotöitä. Malleissa robottitilat ovat lisäksi suhteellisesti yliedustettuina, mikä pienentää tilamallien karjakokoluokkakohtaista keskimääräistä työmäärää. Vuonna 2012 maitotiloista noin 7,7 \%:1la (717) oli käytössä lypsyrobotti ja lypsyrobottitilat tuottivat arvion mukaan noin $19 \%$ maidosta (Manninen 2013).

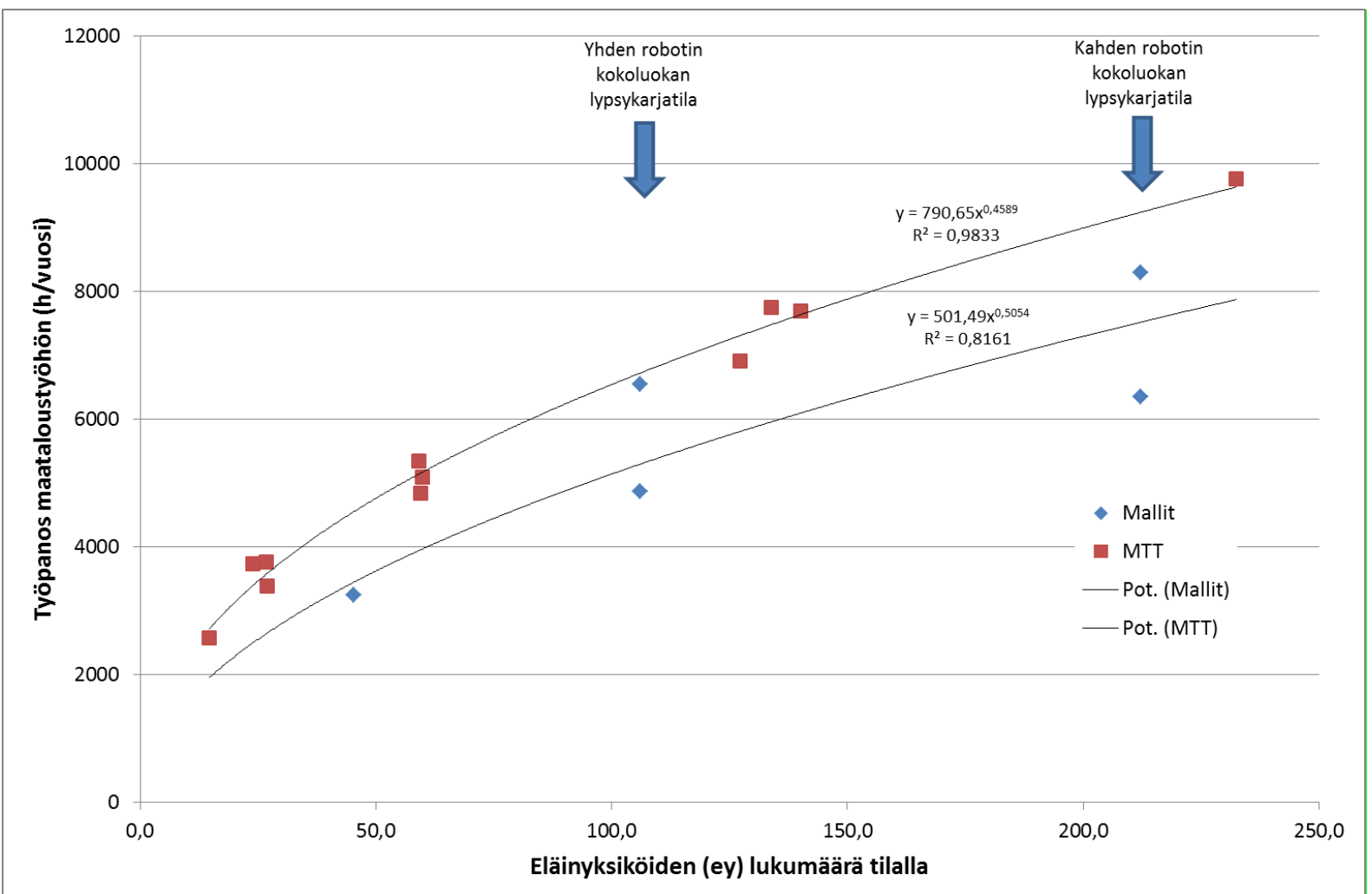

Kuva 1. Tilamallien mukaiset (sininen) vuosittaiset kokonaistyömäärät verrattuna MTT:n kannattavuuskirjanpitoon kuuluvien lypsykarjatilojen (punainen) maataloustyöhön käytettyyn vuosittaiseen työpanokseen (Lähde: MTT:n Taloustohtori; lypsykarjatilat 2011). 
Perusvaihtoehtotilalla kotieläintöiden vuosittainen määrä on noin 2200 h (taulukko 2) eli keskimäärin 73 h/lehmä/vuosi, mikä vastaa noin $67 \%$ kokonaistyömäärästä. Vastaavasti pihattotilamallien kotieläintöiden osuus kaikista tilan töistä on asemalypsytiloilla 70-74 \% ja robottilypsytiloilla 61-65\%. Nämä vastaavat tilakohtaisia kotieläintöiden työmääriä 41-69 h/lehmä/vuosi asemalypsytiloilla ja 28$45 \mathrm{~h} / \mathrm{lehmä/vuosi} \mathrm{robottilypsytiloilla.}$

Peltotöihin liittyvien (tilakeskus-peltolohkot) siirtymien vaatima aika kasvaa varsin samassa suhteessa kuin peltoviljelytöiden kokonaistyömäärä, joten siirtymiin kuluvan ajan osuus peltotöiden kokonaistyömäärästä (2-4\%) pysyy suhteellisen samansuuruisena tai jopa hieman laskee tilakokoluokan kasvaessa. Tarkastelussa on otettava huomioon, että tilakokoluokan kasvaessa peltolohkojen keskietäisyys kasvaa, keskimääräinen ajonopeus kasvaa ja työmenetelmät muuttuvat tehokkaammiksi.

Vastaavasti peltoviljelytöihin liittyviin kuljetuksiin kuluu tilamallitarkastelun perusteella tarkkuussilppuria käyttävillä pihattotiloilla 30-37 \% ja kaksoissilppuria käyttävällä parsinavettatilalla noin $22 \%$ peltotöiden kokonaistyömäärästä. Kuljetuksista suurin osa liittyy säilörehuntuotantoon, mutta lähes sama työmäärä tarvitaan lannankuljetuksiin. Lannankäsittely on peltoviljelytöistä suhteellisesti eniten kuljetusaikaa vievä työ; tilamalleissa 64-73 \% lannankäsittelystä kuluu kuljetuksiin. Siirtymien tavoin tilamallikohtaisiin eroihin vaikuttavat myös kuljetuksissa muutokset peltolohkojen keskietäisyyksissä, keskimääräisissä ajonopeuksissa ja menetelmissä (kuljetuskalustossa).

\section{Työvoimatarve lypsykarjatiloilla}

Maatalousyrittäjän vuosityöpanoksen, 2300 tuntia henkilöä kohti, laskennassa lähtötietona oli TTS:n Jaksaja-projektissa (Karttunen ym. 2012) määritetty viikkotyömääräsuositus 45-48 tuntia ja vuosilomaoikeus (26 päivää/vuosi). Suositus on hyvin yhdenmukainen kannattavuuskirjanpitotiloilta kysytyn kohtuullisen työmäärän (h/päivä sekä h/viikko) sekä MTT:n Taloustohtorin käyttämän työpanosyksikön vuosituntimäärän kanssa. Vastaavasti palkkatyövoiman vuosityöpanoksena käytettiin 1800 tuntia.

Perusvaihtoehtotilan työt edellyttävät noin puolentoista henkilötyövuoden työpanosta sekä säilörehun korjuukaudelle (kaksoissilppuriin perustuva työketju) lisäksi kolmea sesonkityöntekijää (taulukko 3). Perustilaa suuremmissa tilamalleissa maataloustyöt työllistävät kaksi yrittäjää ja asemalypsytiloilla lisäksi yhden (70 lehmän tila) tai kaksi (140 lehmän tila) vakinaista työntekijää. Isoimmilla robottitiloilla (140 lehmän tilat) tarvitaan kasvukauden ajaksi 1-2 työntekijää. Säilörehun korjuutöiden sesonkiin tarvitaan lisäksi pihattotilojen tarkkuussilppurityöketjussa 2-4 sesonkityöntekijää.

Jos suurimman tilakokoluokan (140 lehmää) säilörehun korjuuketju muutetaan ajosilppuriin perustuvaksi, työnmenekki pienenee noin neljänneksen (24-29 \%; noin $135 \mathrm{~h} /$ vuosi). Tehokkaan korjuukoneen takia työketjussa tarvittava henkilömäärä ei kuitenkaan pienene vaan pysyy samana.

Taulukko 3. Perusvaihtoehtotilan ("perustila") eläin- ja peltoresurssit sekä työmäärälaskennan ja vuosityöpanoksen mukaan laskettu tarvittava työvoima (hlöä) + pihattotilojen tilamallikohtaiset lisäystarpeet (perusvaihtoehtotilaan nähden) näissä resursseissa.

\begin{tabular}{|l|l|l|l|l|l|l|l|l|}
\hline \multirow{2}{*}{ Resurssit } & Perustila & \multicolumn{2}{|l|}{ Muutos/lisäystarve (kpl tai ha) perusvaihtoehtoon nähden } \\
\cline { 2 - 8 } & Parsi 30 & Asema 70 & Robo 70 & Asema 140 & Asema 140 hh & Robo 140 & Robo 140 hh \\
\hline Eläimet (yksilöä) & & & & & & & \\
- Lehmät & 30 & +40 & +40 & +110 & +110 & +110 & +110 \\
- Nuorkarja & 25 & +35 & +35 & +96 & -18 & +96 & -18 \\
- Vasikat & 3 & +3 & +3 & +8 & +8 & +8 & +8 \\
\hline Pelto (ha) & 33,9 & $+43,3$ & $+43,3$ & $+120,6$ & $+87,5$ & $+120,6$ & $+87,5$ \\
\hline Työvoima (hlöä) & & & & & & & & \\
- yrittäjät & 1,4 & $+0,6$ & $+0,6$ & $+0,6$ & $+0,6$ & $+0,6$ & $+0,6$ \\
- työväki vaki & 0 & +1 & 0 & +2 & +1 & 0 & 0 \\
- työväki kausi & 0 & 0 & 0 & 0 & +1 & +2 & +1 \\
- työväki sesonki & 3 & -1 & 0 & +1 & +1 & 0 & +1 \\
\hline
\end{tabular}

\section{Töiden ulkoistamisen vaikutus työmäärään ja työvoimatarpeeseen}

Perusvaihtoehtotilan ulkoistaessa kokonaan lannanajon kokonaistyömäärää vähenee vain 1,1\%. Jos lisäksi koko säilörehuntuotanto ulkoistetaan, kokonaistyöaika pienenee 4,9 \%. Jälkimmäisessä vaihtoehdossa 30 lehmän parsinavettatila tarvitsee sesonkityövoimaa lähinnä vain kuivaheinän korjuuseen. Menetelmästä riippuen tarve on 0-2 ulkopuolista henkilöä.

Ulkoistamalla kokonaan lannanajon asemapihattotila vähentää kokonaistyömäärää noin 2,5\% ja ulkoistamalla lisäksi kokonaan säilörehuntuotannon kokonaistyöaika pienenee 9-12\%. Robottilypsy- 
tiloilla vastaavat suhteelliset pienennykset kokonaistyömäärässä ovat 3,4 \% lannanajon ulkoistamisen osalta ja 12-15\% sekä lannanajon että säilörehuntuotannon ulkoistamisen osalta. Edellä mainitut \% määräiset pienennykset pätevät niin yhden kuin kahdenkin robottikokoluokan pihattoihin. Säilörehuntuotantotöistä korjuutöiden osuus työnmenekistä on noin $90 \%$. Hiehon kasvatuksen ulkoistamalla iso pihattotila vähentää kokonaistyömääräänsä noin $8 \%$. (kuva 2)

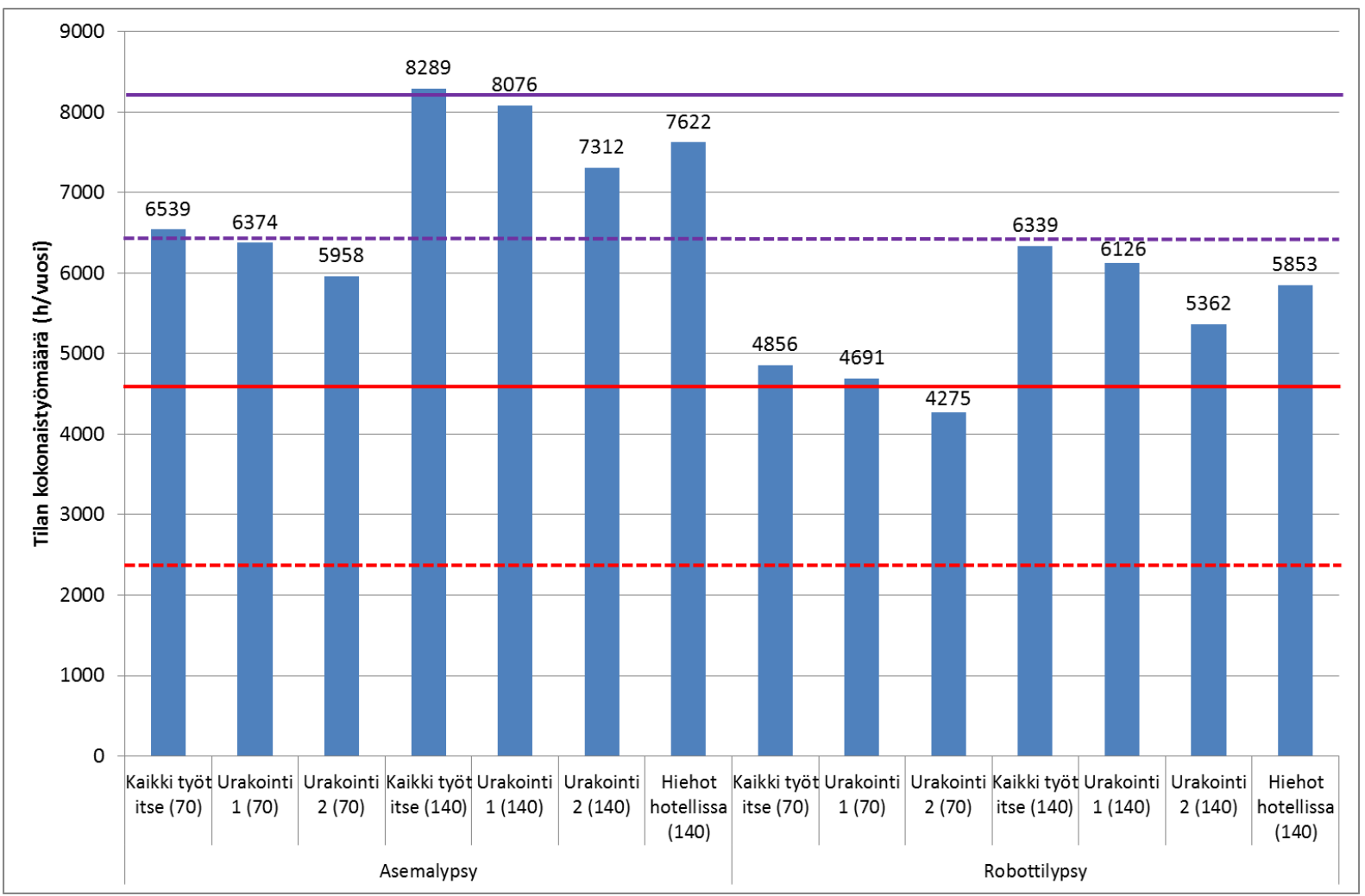

Kuva 2. Tilan kokonaistyömäärä (h/vuosi) 70 lehmän (+ nuorkarja) ja 140 lehmän (+ nuorkarja) maitotiloilla erilaisiin lypsyjärjestelmiin ja työn ulkoistukseen perustuvissa vaihtoehdoissa (Urakointi 1:lannankäsittely ulkoistettu, Urakointi 2: sekä lannankäsittely että säilörehun tuotantotyöt ulkoistettu). Yhden ja kahden yrittäjän vuosittainen työpanos (á $2300 \mathrm{~h}$ ) on merkitty punaisilla vaakaviivoilla, palkkatyöntekijän työpanosta $(1800 \mathrm{~h})$ vastaava työpanos näiden yläpuolelle violetilla viivalla.

Yhden robottikokoluokan (70 lehmää) maitotila työllistää työmäärälaskelmien mukaan kokopäivätoimisesti kaksi yrittäjää. Asemalypsytilalla tarvitaan yrittäjien lisäksi yksi palkkatyöntekijä, jonka työpanoksesta (1800 h/vuosi) voidaan vähentää noin $15 \%$, jos sekä lannankäsittely- että säilörehun tuotantotyöt ulkoistetaan (kuva 2; Urakointi 2 (70) -vaihtoehto). Samalla asemalypsytilalta poistuu kokonaan sesonkityövoiman tarve. Vastaavasti yhden robotin tilalla töitä ulkoistamalla voidaan vähentää omaa työtä sekä poistaa sesonkityövoiman tarve, kun sekä lannankäsittely- että säilörehuntuotantotyöt ulkoistetaan.

Kahden robotin tilakokoluokan (140 lehmää) maitotilalla tarvitaan kahden yrittäjän lisäksi yksi tai kaksi työntekijää asemalypsyvaihtoehdoissa (kuva 2). Jos sekä lannankäsittely- että säilörehun tuotantotyöt ulkoistetaan tai hiehot laitetaan kasvamaan hiehohotelliin, selvitään yhdellä kokoaikaisella palkkatyöntekijällä. Toiselta työntekijältä tarvitaan lisäksi puolen vuoden - 3/4 vuoden työpanosta. Robottilypsyvaihtoehdoissa 140 lehmän tila selviää töistä ilman ympärivuotista palkkatyöntekijää. Käytännössä kuitenkin kaikki peltotyöt ja tilan muut työt (mm. rakennusten ja teiden ylläpito- ja kunnostus, koneiden ja laitteiden huolto ja korjaus, metsätyöt jne.) vaativat ulkopuolisen työvoiman panosta. Näitä kausityöntekijöitä tarvitaan kaksi, jos töitä ei ulkoisteta urakoitsijoille. Lisäksi säilörehun korjuuseen tarvitaan kolme sesonkityöntekijää. Jos robottitila ulkoistaa niin lannankäsittelyn kuin säilörehun tuotannonkin, kausityöntekijöitä tarvitaan vain yksi, kuten hiehohotellivaihtoehdossa.

Tila voi organisoida töitään mm. palkkaamalla työntekijöitä tai ulkoistamalla töitä. Työmäärään ja sitä kautta työvoimatarpeeseen voidaan vaikuttaa myös erikoistumalla tai laaja-alaistumalla sekä erilaisten teknisten ratkaisujen avulla. Esimerkiksi erilaiset lypsyjärjestelmät ja töiden ulkoistamis- 
vaihtoehdot edellyttävät erilaisia investointeja. Käyttämällä urakointipalveluita tilan ei tarvitse investoida kaikkiin töissä tarvittaviin koneisiin. Samalla säästyy myös mm. käyttö-, huolto- ja korjaus-, säilytys- ja vakuutuskulut, jotka tosin sisältyvät urakointihintoihin.

\section{Johtopäätökset}

Asemalypsyyn perustuvien pihattotilamallien avulla tuotetut kotieläintöiden työmäärät (41-69 h/lehmä/vuosi) ovat hyvin samansuuruisia kuin vastaavankokoisilla lypsykarjatiloilla (58-148 lehmää/karja) Saksassa työaikakirjanpidon avulla tutkimuksessa (Mačuhová ym. 2011) kerätyt tiedot (37-62 h/lehmä/vuosi). Myös robottilypsyyn perustuva pihattotilamalli tuotti 70 lehmän karjakokoluokkaan kotieläintyömäärältään (45 h/lehmä/vuosi) vastaavantasoisen tuloksen kuin saksalaistutkimus 60-84 lehmän robottilypsypihattotiloilta $(32-60 \mathrm{~h} / \mathrm{lehmä/vuosi).} \mathrm{Tuloksia} \mathrm{voidaan} \mathrm{näin} \mathrm{pitää}$ työmäärälaskelmien osalta luotettavina.

Käytännössä keskikokoisesta, 30 lehmän maitotilasta laajennus yhden robotin kokoluokkaan saattaa vielä hoitua - robottivaihtoehdossa - vanhoilla pelto- ja työvoimaresursseilla ja jopa vanhoilla koneilla ja menetelmillä; kahden robotin yksikköön siirryttäessä nämä resurssit käyvät riittämättömiksi. Kahden robotin maitotilalla kotieläintyöt hoituvat vielä kahden henkilön voimin, mutta peltoviljelytöihin ja muihin tilan töihin tarvitaan kausityövoimaa. Lisäksi peltoviljelykaluston kapasiteettia on kasvatettava, jotta työt voidaan tehdä oikea-aikaisesti, ja sesonkitöihin tarvitaan työvoimaa, jos kaikki työt tehdään tilalla itse. Ulkoistamalla töitä voidaan vaikuttaa lähinnä sesonkityöntekijöiden sekä peltotöiden koneinvestointien tarpeeseen. Lisäksi hiehojen kasvatuksen ulkoistaminen vähentää nuorkarjatilojen tarvetta, mikä merkitsee pienempää rakennusinvestointia.

Asemalypsyvaihtoehdossa jo 70 lehmän karjakokoluokassa tarvitaan kolmas työntekijä, jotta tilan kaikki työt saadaan tehdyksi. 140 lehmän asemalypsytilalla työntekijätarve nousee neljään työntekijään, jos kaikki työt tehdään itse. Lisäksi tarvitaan sesonkityöntekijöitä sadonkorjuun vilkkaimpiin työsesonkeihin. Ulkoistamalla peltotöitä tai hiehonkasvatus 140 lehmän asemalypsytilalla selvitään kolmella kokoaikaisella työntekijällä, mutta lisäksi tarvitaan 1/2-3/4 palkkatyöntekijän työpanos (yksi kausityöntekijä). Myös asemalypsytilalla peltoviljelykaluston kapasiteettia on kasvatettava 140 lehmän tilakokoluokkaan siirryttäessä, jotta työt voidaan tehdä oikea-aikaisesti.

Maitotilan suunnitellessa merkittävää muutosta tuotantoonsa on tärkeää, että työmäärä- ja työvoimaresurssikysymykset otetaan huomioon. Tällöin tila voi päätöksiä tehdessään valita parhaiten sopivan vaihtoehdon tarjolla olevista ja pitää kunkin henkilön työkuorma kohtuullisena. Näillä ratkaisuilla tuetaan sekä maataloustyötä tekevien jaksamista että kestävää ja laadukasta maataloustuotantoa.

\section{Kirjallisuus}

Auernhammer, H. 1990. Stallsysteme für die Milchviehhaltung im Vergleich - Metode und Ergebnisse. Forschungsbericht Agrartechnik. Habilitation. MEG 182: 1-185.

Kaila, E. \& Tuure, V-M. 2007. Maatilan kokonaistyömäärän hallinta - TTS-Manager työmäärän laskentaohjelma. TTS tutkimuksen tiedote, luonnonvara-ala: maatalous 6/2007 (600): 1-8.

Karttunen, J., Lätti, M. \& Puttonen, S. 2012. Työmäärän hallinta maatalousyrittäjän hyvinvoinnin turvaamisessa. TTS:n tiedote, maataloustyö ja tuottavuus 2/2012 (637): 1-8.

Kauppinen, R. (toim.) 2012. Hiehonkasvatuksen ulkoistaminen - opas kasvattajalle ja ulkoistajalle. Savoniaammattikorkeakoulun julkaisusarja E2/3/2011: 1-74. Juvenes Print - Tampereen Yliopistopaino Oy.

Kivinen, T., Kaustell, K.O., Hakkarainen, K., Tuure, V-M., Karttunen, J. \& Hurme, T. 2007. Lypsykarjapihatoiden toiminnalliset mitoitusvaihtoehdot. MTT:n selvityksiä 137: 1-149.

KTBL. 2010. Datensammlung Betriebsplanung Landwirtschaft 2010/11. Daten für die Betriebsplanung in der Landwirtschaft. 22. Auflage, $784 \mathrm{~s}$.

Mačuhová, J., Heinrich, A. \& Haidn, B. 2011. Determination of labour input on Bavarian dairy farms with four different organization forms. XXXIV CIOSTA CIGR V Conference "Efficient and safe production processes in sustainable agriculture and forestry", 29 June - 1 July 2011, Vienna, Austria.

MMM. 2001. MMM-RMO C4 Kotieläinrakennusten ympäristönhuolto.

Palva, R. 2013. Konetyön kustannukset ja tilastolliset urakointihinnat. TTS:n tiedote, 3/2013 (645): 1-12.

Tuure, V-M. 2012. Työn fyysinen kuormitus ja kuormituksen vähentäminen ajettavien maatalouskoneiden käytössä. Loppuraportti rahoittajalle (Maatalousyrittäjien eläkelaitos). 39 s. Julkaisematon.

Tuure, V-M., Lätti, M. \& Karttunen, J. 2013. Työn tehokkuus isoilla pihattotiloilla: työmäärä, koettu kuormittavuus ja tyytyväisyys. Valion navettaseminaari 24.1.2013 Vantaa - Rantasipi Airport. Esitelmä.

Manninen, E. 2013. Automaattilypsyn osuus jatkaa kasvuaan. Maito ja Me 3/2013. 